Agro-Science Journal of Tropical Agriculture, Food, Environment and Extension Volume 14 Number 2 Mav 2015 pp. $1-8$

ISSN III9-7455

\title{
EFFECT OF WEED CONTROL TREATMENTS AND CUTTING FREQUENCY ON WEED DRY MATTER AND BIOMASS IN RELATION TO THE GROWTH AND YIELD OF FLUTED PUMPKIN (TELFAIRIA OCCIDENTIALIS HOOK F)
}

\author{
Osadebe $^{1}$, V.O. Echezona ${ }^{1}$ B.C. and Bakare ${ }^{2}$ S.O. \\ ${ }^{1}$ Department of Crop Science, University of Nigeria, Nsukka, Enugu State Nigeria. \\ ${ }^{2}$ National Cereals Research Institute, Badeggi, Niger State, Nigeria \\ Corresponding author's e-mail: ogechi_vivian@yahoo.com
}

\begin{abstract}
Two experiments were conducted during the rainy seasons of 2012 and 2013 at the Teaching and Research Farm of the Department of Crop Science, University of Nigeria, Nsukka, to evaluate the growth and leaf yield of Telfairia occidentials Hook F. as influenced by weed control treatments and cutting frequencies. The experimental design was a randomized complete block arranged in a split plot with three replications. The cutting frequencies $(0,2$ and 4 weekly cuttings) represented the main plot, while the sub-plots were six weed control treatments namely weed free, weedy check, hoe weeding at 4 weekly intervals, pre-emergence application of pendimenthalin at $2.25 \mathrm{~kg}$ a.i./ha, black polyethylene mulch and sawdust mulch at 57.2 tonnes/ha. The results of the two years were pooled after Bartellet tests for significance. Data on weed density, weed biomass, weed control efficiency, vine length, number of vines per plant, number of leaves per plant, leaf area, fresh leaf weight per plant and leaf yield were subjected to analysis of variance. Cutting intervals were not significant in most of the parameters assessed. Plots mulched with black polyethylene significantly $(p<0.05)$ performed better than the other weed control treatments in terms of lower number of weeds $\left(3.11 / \mathrm{m}^{2}\right)$, lower weed biomass $\left(3 \mathrm{~g} / \mathrm{m}^{2}\right)$ higher weed control efficiency $(98.61 \%)$, higher crop fresh leaf yield per hectare $\left(2.34 \mathrm{~kg} \mathrm{ha}^{-1}\right)$. Cutting frequency at 4 weekly interval and mulching with black polyethylene within the confines of the study was therefore, recommended for leaf yield production of Telfairia occidentalis.
\end{abstract}

Key words: Fluted pumpkin, growth, leaf yield, weed biomass, weed control treatments.

\section{INTRODUCTION}

Fluted pumpkin (Telfairia occidentalis Hook F.) is one of the most widely cultivated leaf vegetables in south eastern Nigeria. It is gaining recognition in other parts of Nigeria especially, in the North central states. It is generally regarded as a leaf and seed vegetable (Akanbi et al., 2007). It belongs to the family, Cucurbitaceae. The leaves of fluted pumpkin are harvested continually as the plant grows and are used in soups and porridges as the vegetative parts of the crop make an excellent vegetable rich in vitamins. It has $37.3 \%$ protein content on a dry weight basis (Schippers, 2002). The leaf has high nutritional, medicinal and industrial values being rich in protein $29 \%$, fat $18 \%$, minerals and vitamins 20\% (Tindal, 1986). The vegetable contains $20.5 \mathrm{~g}$ proteins, $45 \mathrm{~g}$ fat, $23 \mathrm{~g}$ carbohydrate, $2.2 \mathrm{~g}$ fibre and $4.8 \mathrm{~g}$ total ash (Badifu and Ogunsua, 1991). The oil in the seed could be used for the preparation of margarine and pomade as well as for use as carrier for drugs (Asiegbu, 1987). In the recent time, fluted pumpkin has gained medicinal recognition. It has been discovered to be blood purifier (Aletor et al., 2002) and could therefore be useful in maintenance of good health.

Despite the importance of fluted pumpkin in Nigerian diet, farmers are facing a lot of challenges concerning its production; especially in terms of weed control. In many agricultural systems around the world, competition from weed is one of the major factors reducing yield and farmers income. Weeds caused the greatest yield reduction by competing for moisture, nutrient and light (Knott, 1992; Akobundu, 1986; Olayinka, 2002). Therefore, for a profitable crop production, 
the bulk of labour requirement goes into weed control. Usoroh (1995) reported that for fruits and vegetables, weeding alone accounted for between $45-80 \%$ of the total cost of production in Nigeria. Tijani-Eniola (2001) also reported that weed could cause yield losses ranging from $50-80 \%$. Physical methods of weed control are laborious, tiresome and expensive due to increasing cost of labour, draft animals and implements (Marwat et al., 2008). In view of these facts, the present study was designed to investigate the effect of different weed control methods and cutting frequency on the weeds, growth and yield of fluted pumpkin.

\section{MATERIALS AND METHODS}

Two experiment were conducted at the Teaching and Research Farm of the Department of Crop Science, University of Nigeria, Nsukka, Southeast Nigeria during 2012 and 2013 rainy season. Nsukka is located at latitude $06^{\circ} 52 \mathrm{~N}$ and longitude $07^{\circ} 24^{\prime} \mathrm{E}$; altitude of $447.2 \mathrm{~m}$ above sea level. The area is characterized by a bimodal rainfall pattern with peaks in June and September and a dry spell between mid-July and August. The site was characterized as tropical utisol of sandy loam texture. The study was designed as a randomized complete block in a split-plot arrangement with three replications. The main plots consisted of three cutting frequencies, which are zero (only harvested at the end of the experiment i.e. at 16 weeks after transplanting,) 2 weekly cuttings and 4-weekly cuttings. The sub plots were made up of six weed control treatments: $\left(\mathrm{T}_{1}\right)$ - pre-emergence application of pendimenthalin at $0.66 \mathrm{~kg}$ a.i $/ \mathrm{ha}+$ hand weeding at 4 and 12 weeks after transplanting (WAT), $\left(\mathrm{T}_{2}\right)-$ hoe weeding at $4,8,12$ and 16 weeks after transplanting, $\left(\mathrm{T}_{3}\right)$ - black polyethylene mulch, $\left(\mathrm{T}_{4}\right)$ - sawdust mulch at the rate of 57.2 tonnes/ha + hand weeding at 4 and 12 weeks after transplanting (WAT), $\left(\mathrm{T}_{5}\right.$ ) - weedy check (control $1)$ and $\left(T_{6}\right)$ - weed free (control 2) respectively. In May of both years, a piece of land measuring 63.5 $\mathrm{m}$ long by $16 \mathrm{~m}$ wide with an area of $1,016 \mathrm{~m}^{2}$ was ploughed, harrowed and made into beds. The prepared land was marked out into three blocks of $63.5 \mathrm{~m} \mathrm{x} 4 \mathrm{~m}$ each. Each block was divided into 18 plots of $3 \mathrm{~m} \times 4 \mathrm{~m}$. The crop was planted at a spacing of $1 \mathrm{~m} \times 1 \mathrm{~m}$ to give a population density of 10,000 plants per hectare. Each main plot was separated by $1 \mathrm{~m}$ pathway, while each block is separated by $2 \mathrm{~m}$ pathway. Basal application of decomposed pig dung was incorporated into the soil at $10 \mathrm{~kg} / \mathrm{plot}$ using a garden fork. Seedlings of fluted pumpkin which was grown three weeks earlier in a nursery box was transplanted into the field. The treatments were applied four days before the transplanting. The black plastic mulch was laid before transplanting while transplanting was done through openings made on it at specified spacing. The two middle plants were used as the sampling plant from which data were taken. Fertilizer (N.P.K 20:10:10) was added to each plot in split doses at the rate of $750 \mathrm{~kg} / \mathrm{ha}$ at the $4^{\text {th }}$ and $10^{\text {th }}$ week after transplanting as recommended by Ogar and Asiegbu (2005) using ring application method. Weeding was done accordingly with hoes on the plots requiring weeding while the weedy check plots was left un-weeded from transplanting to the end of the experiment. Harvesting of the vegetable was done by pruning using a sharp knife. Weed identification, density and biomass were determined within two quadrats $\left(0.5 \mathrm{~m}^{2}\right)$ randomly thrown twice in each sub plot at every 4 weeks interval. The weeds within each quadrat were harvested at soil level and oven dried at $70^{\circ} \mathrm{C}$ for 48 hours. Data collection on the crop included vine length, number of vines, leaf area, stem girth, number of leaves per plant, fresh and dry weight of leaves per plant. Leaf yield was obtained using the two middle plants in each sub plot.

The Data on weed infestation and weed density were collected from each unit at 30,60, 90 and 120 days after transplanting (DAT) using a quadrat of $0.5 \mathrm{~m}^{2}$ placed randomly at two different spots in the plot. The weed flora within each quadrat were identified and counted. The average number of two samples was then multiplied by 2 to obtain the weed density per $\mathrm{m}^{2}$. The weed control efficiency was calculated with the following formula by Mani et al., (1973);

Weed control efficiency (WCE) $=$
$\frac{\text { DMC-DMT X } 100}{\text { DMC }}$

Where:

DMC $=$ weed dry matter production in un-weeded treatment

DMT = weed dry matter production in weed control treatment

Weed Index (WI) was calculated with the following formula by Mishra and Tosh, (1979); $\mathrm{WI}(\%)=$ Average yield of crop in weed free plot-Avergage yield of crop in weed control treatment Average yield of crop inweed free plot $x 100$

Some of the data in both years were pooled together after Bartellet test and the means used for analysis. The acquired data was analysed using Genstat statistical package. The means were separated using the Fisher's least significant difference (LSD). 


\section{RESULTS AND DISCUSSION}

Composition of weed species in the experimental plot

A total of 15 weed species within 9 families were identified during the study period (Table 1). About seven three percent $(73.3 \%)$ of the weed species encountered were broadleaves, $13.3 \%$ were grasses while sedges were $13.3 \%$ and about 93.3 $\%$ of the entire weed species were annuals. The most important weed species in other weed control treatments apart from black polyethylene mulch were Ageratum conyzoides, Mimosa invisa, Celosia leptostachyma, Spermacoce verticillata while the Cyperus species were mostly found in the black polyethylene mulch. Weed species diversity was higher in hoe weeded plots, sawdust mulch, pre-emergence application of pendimenthalin, and weedy check plots than in the black polyethylene mulch. This indicates that weed flora composition was being altered by the weed control practices studied. This agrees with the result of the finding of Derksen et al., 1994, Buhler et al., 1997 and Leeson et al., 2000 that farming practices influence the species composition of weed communities in arable fields.

\section{Table 1 Weed species infesting the experimental plots of fluted pumpkin and their} preponderance

\begin{tabular}{|c|c|c|c|c|c|}
\hline $\mathrm{S} / \mathrm{N}$ & Scientific name & Family & Life cycle & Morphology & Weed severity \\
\hline 1 & Ageratum conyzoides Linn. & Asteraceae & Annual & Broadleaf & $* *$ \\
\hline 2 & Calopogonium muconoides Desv & Fabaceae & Annual & Broadleaf & $* *$ \\
\hline 3 & Mimosa pudica Linn. & Mimosoideae & Annual & Broadleaf & $* *$ \\
\hline 4 & Mimosa invisa Mart. & Mimosoideae & Annual & Broadleaf & $* *$ \\
\hline 5 & Celosia leptostachyma Benth. & Amaranthaceae & Annual & Broadleaf & $* * *$ \\
\hline 6 & Mitracapusa villosus (Sw.) DC & Rubiaceae & Annual & Broadleaf & $* * *$ \\
\hline 7 & Aspilia Africana (Pers.) C.D. Adams & Asteraceae & Annual & Broadleaf & $*$ \\
\hline 8 & Phyllantus amarus Schum. \& Thonn & Euphorbiaceae & Annual & Broadleaf & $* *$ \\
\hline 9 & Sclerocarpus africanus Jacq. Ex Murr & Asteraceae & Annual & Broadleaf & $* * *$ \\
\hline 10 & Spermacoce verticillata Linn. & Rubiaceae & Annual & Broadleaf & $*$ \\
\hline 11 & Sida acuta Burm. & Malvaceae & Annual & Broadleaf & $* *$ \\
\hline 12 & Eleucine indica Gaertn. & Poaceae & Annual & Grass & $* *$ \\
\hline 13 & Panicum maximum Jacq. & Poaceae & Annual & Grass & $* * *$ \\
\hline 14 & Cyperus rotundus Linn. & Cyperaceae & Perennial & Sedge & $* * *$ \\
\hline 15 & Cyperus esculentus Linn. & Cyperaceae & Annual & Sedge & $* * *$ \\
\hline
\end{tabular}

$*=$ Less severe, $* *=$ Severe, $* * *=$ Most severe

Table 2: Main effect of cutting frequency and weed control treatments on weed density, biomass and control efficiency of fluted pumpkin

\begin{tabular}{|c|c|c|c|c|c|c|c|c|c|c|c|c|}
\hline \multirow[b]{3}{*}{ Treatments } & \multirow{2}{*}{\multicolumn{4}{|c|}{ Weed density (no./m2) }} & \multirow{2}{*}{\multicolumn{4}{|c|}{$\frac{\text { Weed biomass }(\mathrm{g} / \mathrm{m} 2)}{\text { Days after transplanting }}$}} & \multirow{2}{*}{\multicolumn{4}{|c|}{ Weed control efficiency (\%) }} \\
\hline & & & & & & & & & & & & \\
\hline & 30 & 60 & 90 & 120 & 30 & 60 & 90 & 120 & 30 & 60 & 90 & 120 \\
\hline \multicolumn{13}{|c|}{ Cutting frequency } \\
\hline 0 & 54.10 & 22.70 & 35.70 & 10.24 & 53.00 & 52.90 & 76.00 & 58.00 & 50.22 & 81.69 & 75.49 & 78.30 \\
\hline 2 & 73.70 & 24.70 & 47.80 & 9.01 & 60.30 & 53.10 & 138.00 & 53.00 & 56.55 & 81.55 & 73.84 & 81.28 \\
\hline 4 & 52.40 & 30.30 & 45.20 & 12.08 & 45.20 & 48.80 & 110.00 & 85.00 & 66.47 & 81.15 & 72.84 & 80.99 \\
\hline F-LSD $(0.05)$ & N.S & 5.74 & N.S & N.S & N.S & N.S & N.S & N.S & 10.71 & N.S & N.S & N.S \\
\hline \multicolumn{13}{|l|}{ Weed } \\
\hline \multicolumn{13}{|c|}{ Control treatments } \\
\hline $\mathrm{T}_{1}$ & 90.30 & 27.50 & 87.20 & 14.31 & 40.10 & 7.50 & 53.00 & 10.00 & 66.81 & 96.56 & 80.44 & 95.55 \\
\hline $\mathrm{T}_{2}$ & 80.90 & 28.10 & 56.50 & 13.97 & 83.80 & 8.00 & 38.00 & 11.00 & 31.98 & 96.30 & 82.72 & 92.48 \\
\hline $\mathrm{T}_{3}$ & 0.00 & 6.10 & 11.20 & 3.11 & 0.00 & 1.60 & 2.00 & 3.00 & 100.00 & 99.38 & 99.26 & 98.61 \\
\hline $\mathrm{T}_{4}$ & 67.20 & 22.60 & 50.40 & 11.06 & 60.30 & 2.90 & 66.00 & 4.00 & 51.90 & 98.91 & 83.28 & 97.86 \\
\hline $\mathrm{T}_{5}$ & 112.40 & 57.10 & 40.60 & 16.83 & 127.90 & 284.70 & 484.00 & 361.00 & 0.00 & 0.00 & 0.00 & 0.00 \\
\hline $\mathrm{T}_{6}$ & 9.60 & 14.20 & 11.40 & 3.39 & 4.90 & 4.90 & 4.00 & 5.00 & 95.79 & 97.63 & 98.66 & 96.64 \\
\hline F-LSD $(0.05)$ & 25.60 & 9.40 & 22.60 & 2.52 & 15.43 & 27.46 & 135.00 & 99.30 & 10.26 & 1.87 & 8.38 & 2.97 \\
\hline
\end{tabular}


Effect of Weed Control Treatment and Cutting Frequency of Weed dry Matter and Biomass

Weed density and weed biomass

Cutting frequency did not significantly influence weed infestation considerably, and it was manifested in both density as well as biomass of weeds (Table 2). The result reveals that all weed control treatments decreased significantly $(\mathrm{p}<0.05)$ the number and dry weight of weeds from 30 to 120 DAT as compared to the weedy check. At 30 to 120 DAT, weedy check consistently recorded significantly $(\mathrm{p}<0.05)$ higher weed density compared with weed free plots. Weed density recorded with the plots with pendimentialin at $0.66 \mathrm{~kg}$ a.i $/$ ha was statistically similar to that recorded in hoe-weeded plots at 4 weekly intervals but significantly $(\mathrm{p}<0.05)$ lower than that recorded in black polyethylene mulch and weed free plots. Again, weedy check recorded significantly ( $\mathrm{p}<0.05$ ) higher weed biomass $\left(361 \mathrm{~g} / \mathrm{m}^{2}\right)$ at 120 DAT which was significantly $(\mathrm{p}<0.05)$ higher than what was recorded in the other weed control treatments. The least weed biomass $\left(3.0 \mathrm{~g} / \mathrm{m}^{2}\right)$ were recorded in plots mulched with black polyethylene. This is in agreement with the report of Hashim et al., (2003) who reported higher weed dry biomass in weedy check relative to the other treatments. Boydston and Vaughn (2002) noted that chemical weed control significantly $(\mathrm{p}<0.05)$ reduced the weed biomass. The weed dry weight under black plastic mulch showed an increased trend as the days after transplanting increased probably because of the decline in the strength of the plastic mulch due to exposure to harsh weather conditions. The reason for lower weed dry weight in black polyethylene mulch compared to weed free plots was attributed to poor transmittance of light in the black polyethylene mulch, which resulted in reduced photosynthetic activity of the weeds. This would have resulted in poor germination of the seeds and growth of the weeds (Subrahmaniyan et al., 2011). The result of the findings is in agreement with the report of Shrivastava et al., (1994) who reported that black plastic mulch reduced weed infestation by $95 \%$ but disagrees with the report of Hidayat et al., (2013) who reported that weedy check recorded dry weed biomass, which was comparable with black plastic mulch. Ngouajio et al.(2008) also reported complete elimination of weeds with the use of black polyethylene mulch. Black polyethylene mulch reduced weed emergence, except a few, which emerged through the planting holes (Schonbeck, 1999). Black mulch effectively checked weed growth by intercepting nearly all-incoming radiation (Schonbeck, 1999).

Table 3: Main effect of cutting frequency and weed control treatments on morphological parameters of Fluted pumpkin at 4 and 8 weeks after transplanting

\begin{tabular}{|c|c|c|c|c|c|c|c|c|c|c|}
\hline \multirow[b]{2}{*}{ Treatments } & \multicolumn{5}{|c|}{ 4th week } & \multicolumn{4}{|c|}{ 8th week } & \multirow[b]{2}{*}{$\begin{array}{l}\text { Number } \\
\text { of } \\
\text { branches }\end{array}$} \\
\hline & $\begin{array}{c}\text { Leaf area } \\
\left(\mathrm{cm}^{2}\right)\end{array}$ & $\begin{array}{l}\text { Number of } \\
\text { leaves/plant }\end{array}$ & $\begin{array}{c}\text { Stem } \\
\text { girth }(\mathrm{cm})\end{array}$ & $\begin{array}{c}\text { Vine } \\
\text { length }(\mathrm{cm})\end{array}$ & $\begin{array}{c}\text { Number } \\
\text { of } \\
\text { branches }\end{array}$ & $\begin{array}{c}\text { Leaf } \\
\operatorname{area}\left(\mathrm{cm}^{2}\right)\end{array}$ & $\begin{array}{l}\text { Number of } \\
\text { leaves/plant }\end{array}$ & $\begin{array}{c}\text { Stem } \\
\text { girth }(\mathrm{cm})\end{array}$ & $\begin{array}{c}\text { Vine } \\
\text { length }(\mathrm{cm})\end{array}$ & \\
\hline \multicolumn{11}{|c|}{ Cutting frequency } \\
\hline 0 & 138.1 & 29.33 & 1.26 & 64.1 & 3.92 & 282.8 & 70.4 & 1.774 & 150.3 & 8.22 \\
\hline 2 & 132.78 & 29.49 & 1.28 & 60.7 & 4.08 & 215.1 & 47.4 & 1.666 & 85.6 & 7.49 \\
\hline 4 & 148.08 & 31.9 & 1.33 & 67.4 & 3.93 & 236.5 & 52.8 & 1.822 & 117.1 & 7.61 \\
\hline F-LSD $(0.05)$ & N.S & N.S & N.S & N.S & N.S & 40 & 14.69 & N.S & 19.41 & N.S \\
\hline \multicolumn{11}{|c|}{ Weed control treatments } \\
\hline $\mathrm{T} 1$ & 154.25 & 33.22 & 1.326 & 72.5 & 3.92 & 247 & 64.9 & 1.889 & 133.1 & 7.42 \\
\hline $\mathrm{T} 2$ & 134.27 & 28.72 & 1.246 & 64.6 & 4.08 & 259.8 & 51.1 & 1.607 & 114.1 & 7.72 \\
\hline T3 & 107.71 & 30.28 & 1.38 & 47.4 & 4.42 & 300.3 & 80.4 & 1.914 & 114.3 & 12.42 \\
\hline $\mathrm{T} 4$ & 136.2 & 27.92 & 1.269 & 59.4 & 3.78 & 207.2 & 52.3 & 1.729 & 115.2 & 7.36 \\
\hline T5 & 153.26 & 28.78 & 1.255 & 71.8 & 3.78 & 187.1 & 25.5 & 1.432 & 96 & 3.67 \\
\hline T6 & 152.25 & 32.53 & 1.266 & 68.6 & 3.89 & 267.5 & 66.8 & 1.952 & 133.3 & 8.06 \\
\hline F-LSD $(0.05)$ & 30.16 & N.S & N.S & 12.64 & N.S & 44.65 & 12.98 & 0.221 & 21.5 & 1.726 \\
\hline
\end{tabular}

$\mathrm{T}_{1}=$ Pendimenthalin at $0.66 \mathrm{~kg}$ a.i./ha, $\mathrm{T}_{2}=$ Hoe Weeding at 4 weekly intervals, $\mathrm{T}_{3}=$ Black polyethylene mulch, $\mathrm{T}_{4}=$ Sawdust cover at 57.2 tonnes $/$ ha, $\mathrm{T}_{5}=$ Weedy check, $\mathrm{T}_{6}=$ Weed free, N.S $=$ Not significant. 
Osadebe, V.O. Echezona B.C. and Bakare S.O.

\section{Weed control efficiency (WCE)}

Data in Table 2 shows that the cutting frequency had significant effect on the WCE at 30 DAT. Cutting frequency at 4 weekly interval produced significantly $(\mathrm{p}<0.05)$ lower WCE $(66.47 \%)$ than the cutting interval of 2 weekly intervals. Weed control efficiency of black polyethylene mulch was significantly ( $\mathrm{p}<$ 0.05 ) higher than the other weed control treatments. There were fewer weed growth in weed free and black plastic mulch treatments at early crop growth stages, and negligible weed growth was noticed at the later stages. Apart from the weed free condition, the highest WCE was observed in plots mulched with black polyethylene. The results revealed that irrespective of treatment, weed infestation increased at the end of the planting season leading to lesser weed control efficiency. This might be due to reduction in the toxicity of the applied chemical and strength of the mulch resulting in higher weed infestation and thus reduced WCE. This agrees with the report of Subrahmaniryan et al., (2011) that weed control efficiency and weed index were highest with black polyethylene film mulch. However, the lower weed control efficiency recorded with weedy check was due to higher total weed population and total weed dry weight.

\section{Effect of cutting frequency and weed control treatments on morphological parameters}

Cutting frequency did not show any significant effect on the leaf area at 4 weeks after transplanting but at 8 weeks after transplanting. Cutting interval of zero (0) gave significantly $(\mathrm{p}<0.05)$ higher leaf area $(282.8$ $\mathrm{cm}^{2}$ ) (Table 2). Among the weed control treatments, black polyethylene mulch plots recorded significantly $(\mathrm{p}<0.05)$ higher leaf area at 8 WAT $\left(300.3 \mathrm{~cm}^{2}\right)$ which was comparable with that obtained from hoeweeding $\left(259.8 \mathrm{~cm}^{2}\right)$ and weed free plots $\left(267.5 \mathrm{~cm}^{2}\right)$, while the least was obtained in the weedy check (187.1 $\mathrm{cm}^{2}$ ). The number of leaves followed the same trend as the results obtained for leaf area. There was no significant effect of cutting frequency on stem girth at 4 and 8 WAT (Table 2). At 8 WAT, plots with pendimenthalin recorded higher value $(1.889 \mathrm{~cm})$ when compared with the other weed treatment options with the least recorded by weedy check $(1.432 \mathrm{~cm})$.

Cutting frequency had no significant effect on vine length at 4 WAT but at 8 WAT. Zero cutting recorded higher value $(150.3 \mathrm{~cm})$, while the lowest $(85.6 \mathrm{~cm})$ vine length was recorded in 2- weekly cutting interval. Among the weed control treatments at 8 WAT, the highest vine length of $115.2 \mathrm{~cm}$ and 114.3 were recorded in sawdust mulch, black polyethylene mulch respectively while the lowest $(96.0 \mathrm{~cm})$ vine length were recorded in weedy check plots. There was no significant effect of cutting interval on number of vines per plant at 4 and 8 WAT but among the weed control treatments, highest number of vines 12.42 plant $^{-1}$ was found in black polyethylene mulched plots and the minimum number of vines 3.67 was recorded in the weedy check. The increased vine length in mulched plants was possible due to better availability of soil moisture and optimum soil temperature provided by the mulches. Ali and Khan (2008) reported significant effect of mulches on the number of branches per plant in okra plant. Also Hamidreza et al., (2012) and Masarirambi et al., (2013) observed that plants grown with mulch had higher plant height, stem diameter and leaf area when compared with no mulch or weedy plots. Rajablarijani et al., (2012) observed an increase on the number of branches and leaves for the plants grown with plastic mulch compared to bare soil. The findings of the study were also consistent with the findings by Matsenjwa (2006) who reported that both plastic and organic mulch increased plant height of field bean under similar conditions. 
Table 4: Main effect of weed control treatments on the yield parameters of fluted pumpkin at zero (0) cutting in 2012 and 2013 planting seasons

\begin{tabular}{|c|c|c|c|c|c|c|c|c|c|c|c|c|c|c|c|}
\hline \multirow{2}{*}{$\begin{array}{l}\text { Weed } \\
\text { control } \\
\text { treatment }\end{array}$} & \multicolumn{3}{|c|}{$\frac{\text { Fresh weight/plant }}{\underline{(\mathrm{g})}}$} & \multicolumn{3}{|c|}{$\underline{\text { Dry weight/plant (g) }}$} & \multicolumn{3}{|c|}{$\underline{\text { Weed index }(\%)}$} & \multicolumn{3}{|c|}{$\underline{\text { Number of vine cut }}$} & \multicolumn{3}{|c|}{$\underline{\text { Yield (kg/ha) }}$} \\
\hline & 2012 & 2013 & Mean & 2012 & 2013 & Mean & 2012 & 2013 & Mean & 2012 & 2013 & Mean & 2012 & 2013 & Mean \\
\hline $\mathrm{T}_{1}$ & 1190.00 & 449.00 & 819.50 & 207.00 & 74.00 & 140.50 & -19.46 & -2.27 & -10.87 & 5.50 & 2.50 & 4.00 & 15.47 & 7.73 & 11.60 \\
\hline $\mathrm{T}_{2}$ & 606.00 & 501.00 & 553.50 & 123.90 & 89.90 & 106.90 & 7.87 & -4.13 & 1.87 & 6.33 & 4.83 & 5.58 & 11.78 & 7.86 & 9.82 \\
\hline $\mathrm{T}_{3}$ & 898.00 & 1252.00 & 1075.00 & 155.00 & 198.70 & 176.85 & -8.41 & -132.25 & -70.33 & 4.17 & 7.17 & 5.67 & 14.03 & 17.57 & 15.80 \\
\hline $\mathrm{T}_{4}$ & 324.00 & 433.00 & 378.50 & 60.70 & 73.50 & 67.10 & 21.90 & -37.09 & -7.60 & 5.17 & 5.50 & 5.34 & 10.12 & 10.34 & 10.23 \\
\hline $\mathrm{T}_{5}$ & 124.00 & 228.00 & 176.00 & 19.70 & 40.00 & 29.85 & 94.20 & 72.90 & 83.55 & 2.00 & 2.17 & 2.09 & 0.75 & 2.01 & 1.38 \\
\hline $\mathrm{T}_{6}$ & 567.00 & 427.00 & 497.00 & 111.10 & 100.10 & 105.60 & 0.00 & 0.00 & 0.00 & 4.67 & 3.50 & 4.09 & 12.95 & 7.59 & 10.27 \\
\hline $\begin{array}{l}\text { Grand } \\
\text { Mean }\end{array}$ & 618.00 & 548.00 & $\mathbf{5 8 3 . 0 0}$ & 113.00 & 96.00 & 104.50 & 16.00 & -17.40 & -0.70 & 4.64 & 4.28 & 4.46 & 10.85 & 8.85 & 9.85 \\
\hline $\begin{array}{l}\text { F- } \\
\operatorname{LSD}_{(0.05)}\end{array}$ & NS & 290.50 & & 99.40 & 55.74 & & 18.89 & 20.51 & & 2.26 & 1.68 & & 2.55 & 1.73 & \\
\hline
\end{tabular}

$\mathrm{T}_{1}=$ Pendimenthalin at $0.66 \mathrm{~kg}$ a.i./ha, $\mathrm{T}_{2}=$ Hoe Weeding at 4 weekly intervals, $\mathrm{T}_{3}=$ Black polyethylene mulch, $\mathrm{T}_{4}=$ Sawdust cover at 57.2 tonnes $/$ ha, $\mathrm{T}_{5}=$ Weedy check, $\mathrm{T}_{6}=$ Weed free, N.S = Not significant.

Table 5: Main effect of weed control treatments on the yield parameters of fluted pumpkin at 2 weekly cutting intervals in 2012 and 2013 planting seasons

\begin{tabular}{|c|c|c|c|c|c|c|c|c|c|c|c|c|c|c|c|}
\hline \multirow{2}{*}{$\begin{array}{l}\text { Weed control } \\
\text { treatment }\end{array}$} & \multicolumn{3}{|c|}{ Fresh weight/plant(g) } & \multicolumn{3}{|c|}{ Dry weight/plant (g) } & \multicolumn{3}{|c|}{ Weed index (\%) } & \multicolumn{3}{|c|}{$\underline{\text { Number of vine cut }}$} & \multicolumn{3}{|c|}{ Yield (kg/ha) } \\
\hline & 2012 & 2013 & Mean & 2012 & 2013 & Mean & 2012 & 2013 & Mean & 2012 & 2013 & Mean & 2012 & 2013 & Mean \\
\hline $\mathrm{T}_{1}$ & 127.90 & 41.30 & 84.60 & 19.46 & 7.14 & 13.30 & 32.09 & -29.43 & 1.33 & 3.33 & 1.98 & 2.66 & 1.10 & 0.91 & 1.01 \\
\hline $\mathrm{T}_{2}$ & 61.40 & 51.80 & 56.60 & 9.44 & 6.60 & 8.02 & 62.35 & -5.38 & 28.49 & 3.29 & 1.79 & 2.54 & 0.66 & 0.72 & 0.69 \\
\hline $\mathrm{T}_{3}$ & 192.60 & 59.40 & 126.00 & 27.10 & 8.96 & 18.03 & 3.41 & -23.01 & -9.80 & 6.04 & 1.75 & 3.90 & 1.65 & 1.04 & 1.35 \\
\hline $\mathrm{T}_{4}$ & 104.10 & 81.90 & 93.00 & 15.71 & 11.12 & 13.42 & 59.48 & -26.47 & 16.51 & 3.75 & 2.04 & 2.90 & 0.69 & 1.01 & 0.85 \\
\hline $\mathrm{T}_{5}$ & 24.60 & 16.50 & 20.55 & 3.35 & 3.82 & 3.59 & 79.39 & 65.23 & 72.31 & 1.72 & 1.33 & 1.53 & 0.12 & 0.17 & 0.15 \\
\hline $\mathrm{T}_{6}$ & 157.70 & 32.60 & 95.15 & 23.40 & 5.08 & 14.24 & 0.00 & 0.00 & 0.00 & 4.75 & 1.46 & 3.11 & 1.55 & 0.58 & 1.07 \\
\hline Grand mean & 111.00 & 47.30 & 79.15 & 16.40 & 7.10 & 11.75 & 39.80 & -3.18 & 18.31 & 3.79 & 1.73 & 2.76 & 0.96 & 0.74 & 0.85 \\
\hline F-LSD $(0.05)$ & 70.30 & N.S & & 10.79 & N.S & & 19.15 & 39.10 & & 2.14 & N.S & & 0.39 & N.S & \\
\hline
\end{tabular}

$\mathrm{T}_{1}=$ Pendimenthalin at $0.66 \mathrm{~kg}$ a.i./ha, $\mathrm{T}_{2}=$ Hoe Weeding at 4 weekly intervals, $\mathrm{T}_{3}=$ Black polyethylene mulch, $\mathrm{T}_{4}=$ Sawdust cover at 57.2

tonnes $/$ ha, $\mathrm{T}_{5}=$ Weedy check, $\mathrm{T}_{6}=$ Weed free, $\mathrm{N} . \mathrm{S}=$ Not significant.

Table 6: Main effect of weed control treatments on the yield parameters of fluted pumpkin at 4 weekly cutting intervals in 2012 and 2013 planting seasons

\begin{tabular}{|c|c|c|c|c|c|c|c|c|c|c|c|c|c|c|c|}
\hline \multirow{2}{*}{$\begin{array}{l}\text { Weed control } \\
\text { treatments }\end{array}$} & \multicolumn{3}{|c|}{ Fresh weight/plant (g) } & \multicolumn{3}{|c|}{ Dryweight/plant (g) } & \multicolumn{3}{|c|}{ Weed index (\%) } & \multicolumn{3}{|c|}{$\underline{\text { Number of vine cut }}$} & \multicolumn{3}{|c|}{$\underline{\text { Yield (kg/ha) }}$} \\
\hline & 2012 & 2013 & Mean & 2012 & 2013 & Mean & 2012 & 2013 & Mean & 2012 & 2013 & Mean & 2012 & 2013 & Mean \\
\hline $\mathrm{T}_{1}$ & 196.00 & 99.00 & 147.50 & 31.10 & 13.50 & 22.30 & 21.40 & -42.71 & -10.66 & 4.96 & 2.00 & 3.48 & 1.53 & 1.75 & 1.64 \\
\hline $\mathrm{T}_{2}$ & 259.00 & 120.00 & 189.50 & 40.70 & 14.40 & 27.55 & 8.87 & 4.39 & 6.63 & 4.92 & 3.00 & 3.96 & 1.90 & 1.18 & 1.54 \\
\hline $\mathrm{T}_{3}$ & 273.00 & 134.00 & 203.50 & 43.10 & 16.90 & 30.00 & -8.04 & -81.47 & -44.76 & 5.87 & 3.58 & 4.73 & 2.63 & 2.34 & 2.485 \\
\hline $\mathrm{T}_{4}$ & 182.00 & 131.00 & 156.50 & 27.90 & 18.10 & 23.00 & 31.47 & -45.43 & -6.98 & 4.79 & 2.62 & 3.71 & 1.61 & 1.82 & 1.715 \\
\hline $\mathrm{T}_{5}$ & 31.00 & 54.00 & 42.50 & 3.80 & 7.40 & 5.60 & 74.77 & 52.77 & 63.77 & 1.60 & 2.04 & 1.82 & 0.16 & 0.45 & 0.305 \\
\hline $\mathrm{T}_{6}$ & 312.00 & 100.00 & 206.00 & 47.40 & 14.40 & 30.90 & 0.00 & 0.00 & 0.00 & 6.46 & 2.33 & 4.40 & 2.23 & 1.19 & 1.71 \\
\hline Grand mean & 209.00 & 106.00 & $\mathbf{1 5 7 . 5 0}$ & 32.30 & 14.10 & 23.20 & 21.30 & -18.74 & 1.28 & 4.77 & 2.60 & 3.69 & 1.68 & 1.46 & 1.57 \\
\hline F-LSD $(0.05)$ & 110.10 & N.S & & 17.90 & N.S & & 34.99 & N.S & & 2.52 & 1.02 & & 0.73 & 1.07 & \\
\hline
\end{tabular}




\section{Effect of weed management on yield data}

Black polyethylene mulch gave significantly ( $p<$ $0.05)$ higher leaf fresh weight $(898 \mathrm{~g}$ and $125 \mathrm{~g})$ and leaf dry weight per plant (155 g and $198.7 \mathrm{~g}$ ) in both seasons compared to the weedy check plots which consistently gave the lowest leaf fresh weight (124 g and $228 \mathrm{~g})$ and dry weight (19.70 and 40.0), respectively (Table 4). Weedy check recorded consistently higher weed index in both seasons (94.2 and $72.90 \%$ ) and had showing a decrease in yield in both seasons. Black polyethylene mulched plots recorded higher number of harvested vines and higher yield, which is similar to that, obtained in sawdust mulched plots. The same trend was also repeated in Table 5 and 6 . The above results are corroborated with the findings of Singh and Kamal (2012) and Hatami et al., (2012), who reported that higher yield in tomato was obtained in black polyethylene mulch than the other mulch materials used.

\section{REFERENCES}

Akanbi, W.B. Adeboye, C.O., Togun, A.O., Ogunrinde, J.O. and Adeyeye, S.A. (2007). Growth herbage and Seed yield and quality of Telfairia occidentials as influenced by Cassava peel Compost and Mineral Fertilizer. World Journal of Agricultural Science 3(4):308-316.

Akobundu I.O. (1986). Weed and their control In: Introduction to Tropical Agriculture edited by A. Youdeowei, F.O.C. Ezedinma and O. C. Onazi. London, Longmans, 160-179 pp.

Aletor, O., Oshodi A.A. and Ipinmoroti, K. (2002). Chemical composition of common leafy vegetable and functional properties of their leaf protein concentrates. Food chemistry, 78:63-68.

Ali, S. and Khan, I.A. (2008). Effect of different mulches on weed flora and yield of Okra (Abelmoschus esculentus L.). M.Sc. Thesis of Department of Weed Science, the University Agric. Peshawar. Pp. 1-51.

Asiegbu J.E. (1987). Some biochemical evaluation of fluted pumpkin seed. J.Sci. Food Agric 40: 151-155.

Badifu, S.I. O., Ogunsua, A.O., (1991). Chemical Composition of Kernels from some species of cucurbitaceae grown in Nigeria. Plant Food Human Nutrition 41:35-44.

Boydston, R.A. and Vaughn S. (2007). Alternative weed management systems control weeds in potato (Solanum tuberosum) Weed Technol. 16 (1): 23-28.

Buhler, D.D., Hartzler, R.G., Forcella, F. (1997). Implications of Seed band dynamics to weed management. Weed Sci. 45:329336.

Carmichael, P.C., Shongwe, V.D., Masarirambi, M.T. and Manyatsi, A.M. (2012).Effects of mulch and mulch and tillage on maize productivity and soil irrigation on growth, yield and quality of radish (Raphaus sativas). Asian J. Agric. Sci., 4 (3): 183187.

Derksen, D.A., Thomas, A.G., Lafond G.P., Loeppky, H.A., Swanton C.I., (1994). Impact of agronomic practices on weed communities: Fallow within tillage systems. Weed. Sci. 42, 184-194.

Hamidreza, R., Ramin, R., and Farzad, H. (2012). Using coloured plastic mulch in tomato (Lycopersicon esculentum L.) production. $4^{\text {th }}$ International Conference on Agriculture and Animal Science vol 47(3).

Hashim, S, Marwat, K.B. and Hassan, G. (2003). Chemical weed control efficiency in potato (Solanum tuberosum L.) under Agroclimatic conditions of Peshawar, Pakistan. Pak. J. Weed Sci. Res. 10 (34):157-160.

Hatami, S, Nourjou, A., Henareh, M., and Pourakbar, L. (2012). Comparison effects of different methods of black plastic mulching and planting patterns on weed control, water use efficiency and yield in tomato crops. International Journal of Agri Science 2(10):928-934.

Hidayat, H., Hassan, G., Khan, I., Khan M.I. and Khan I.A. (2013).Effect of Different Mulches and herbicides on potato and associated weeds. Pak. J. Weed Sci. Res. 19(2):191-200.

Knott, C.M. (1992). Weed control in other arable and field vegetable crops. Agronomy Journal 76:85-92.

Leeson, J.Y., Sheard, J.W., Thomas A.G. (2000). Weed communities associated with arable Saskat Chewan farm management systems. Can. J. Plant Sci. 890:177-185.

Mani, V. S., Gautam, K. C. and Bhagwandas (1973). Indian Farming 23:17-18.

Marwat, K.B., Muhammad, S., Zahid Hussain, B and Haroon -ur-Rashid, (2008). Study of various weed management practices for weed control in wheat under irrigated 
conditions. Pakistan Journal of weed science Research, 14(1-2): 1-8.

Masarirambi, M.T., Mndzebele, M.E., Wahome, P.K., and Oseni, T.O. (2013).Effect of white plastic and Sawdust mulch on 'Savoy' Baby cabbage (Brassica oleracea var. bullata) growth, yield and soil moisture conservation in summer in Swaziland. American-Eurasian J. Agric. and Environ. Sci. 13 (2): 261-268.

Matsenjwa, N.V, (2006). Influence of mulch on Ecological and Agronomic characteristics of field Bean (Phaseolus vulgaris L.) in Luyengo. Unpublished B.Sc. Agricultural Dissertation, University of Swaziland, Luyengo, Swaziland.

Mishra, A. and Tosh, G. C. (1979). Chemical weed control studies on dwarf wheat. $I$. Res.10:1-6.

Ngouajio, M., Auras, R., Fernadndez, R.T., Rubino, M., Counts, J.W. and Kijchavengkul, T. (2008). Field performance of aliphatic-aromatic copolyester biodegradable mulch films in a fresh market tomato production system. Hort. Technology 18:605-610.

Ogar E.A. and Asiegbu, J.E. (2005).Effects of fertilizer rates and cutting frequency on the marketable vegetable and pod yields in fluted pumpkin in southeastern Nigeria. Journal of Agric, Food, Environment and Extension 4(1): 66-69.

Olayinka B. (2002). Effect of N.P.K. fertilizer level on yield of Okra-sweet corn intercrop and post harvest quality of Okra fruit. Unpublished M.Sc. thesis Department of Agronomy, University of Ibadan, Ibadan, Nigeria.

Rajablarijani, H.R., Hassankhan, F., and Rafezi, R. (2012). Effect of coloured plastic mulches on yield of tomato and weed biomass. International Journal of Environmental Science and Development, 3(6): 590-593.

Schippers, R.R. (2002). African Indigenous Vegetable: an overview of the cultivated species. Revised edition on CD-ROM National Resource International Limited. Ayles food United Kingdom pp. 214.
Schonbeck, M.W. (1999). Weed suppression and labour costs associated with organic, plastic and paper mulches in small scale vegetable production. J. Sustain. Agric. 13:13-33.

Shravastava P.K., Parikh M.M., Sawani N.G. and Raman S. (1994). Effect of drip irrigation and mulching on tomato yield. Agricultural Water Management 25:179184.

Singh, A.K. and Kamal, S. (2012). Effect of black plastic mulch on soil temperature and tomato field in mid hills of Garhwal Himalayas. Journal of Horticulture and Forestry 4(4): 78-80.

Subrahmaniyan, K., Zhou, W. and Veeramani P. (2011). Weed control through degradable, herbicidal plastics and organic mulches and their effect on crop growth and yield of winter rape seed (Brassica napus). India Journal of Agricultural Sciences 81(4): 348-352.

Tijani-Eniola H. (2001). Influence of Intra-raw spacing and weeding regime on the performance of Cowpea (Vigna ungniculata (L) Walp). Nigerian J. of Weed Science 14:11-15.

Tindal, H.D (1986). Vegetables in the Tropics. MacMillan Education Ltd. Hound mills, Hampshire. 533 pp.

Usoroh, N.J. (1995). Effective weed control strategies for fruit and vegetable production in Nigeria. Paper presented at National workshop on farming systems for sustainable production fruits and vegetables held at NIHORT, Ibadan, Nigeria. 